\title{
19. Introduction
}

\section{A. Viergever ${ }^{1}$ and W. Sauer}

\section{BACKGROUND}

Eurostat, the Statistical Office of the European Communities, has embarked on a project to define pressure indicators for ten of the major policy fields within the EU's environmental policy, as laid down in the Fifth Environmental Action Programme (5EAP). ${ }^{2}$ One of these ten policy fields is Resource Depletion, which is the subject of this part of the volume. Elements of the Eurostat project comprise the operationalization of the ten policy fields in terms of delimitation with respect to other policy fields. Three essays, drafted by noted experts within each policy field, contributed to this aim and also provided a starting-point for the development of a limited set of about thirty indicators per policy field. Based on these essays, the suggestions made by the 'Scientific Advisory Groups' (SAGs - some 200-300 experts per policy field throughout the EU) and the expertise from earlier projects, INFOPLAN Environmental Consultants, contractors of Eurostat, have created a framework allowing the delimitation, aggregation and positioning of indicators for Resource Depletion on a European scale.

The potential indicators were obtained by sending a questionnaire to the SAG for Resource Depletion, asking for suggestions. This produced a huge and heterogeneous set of indicators, which had to be reduced to a 'manageable' set of specific pressure indicators for Resource Depletion, to be used as the basis for the second round of the survey - the ranking of the indicators. Similar suggestions were grouped into pressure indicators which are compatible, as far as possible, with those already identified or in use by the OECD, the EC and/or the appropriate Member State organizations and agencies, producing 27 indicators for Resource Depletion. The SAGs were asked to rank these indicators according to the three quality criteria of policy relevance, analytical soundness and responsiveness. The SAGs were also asked to rank their top five 'core indicators'. Figure 19.1 shows the results of the 'quality' questions with indicators ranked from 1 (very low) to 4 (very high) and core rankings expressed as a percentage of experts who included the indicator in their top five list of essential indicators. 
Pressure indicators for resource depletion: ‘quality' questions Q1-3, core-ranked
Ranking ( 1 = very low, 4 = very high):

Dolicy relevance

$\square$ Analytical soundness

$\square$ Responsiveness

- Core ranking (right scale)
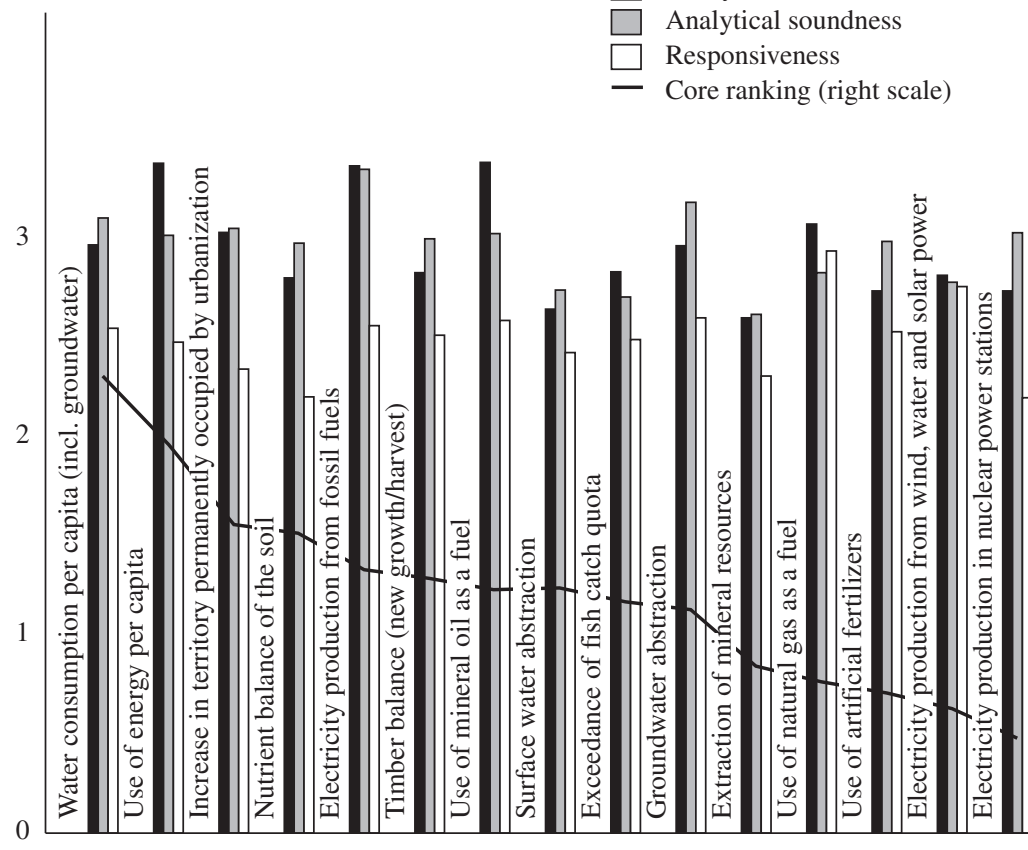

Figure 19.1 Results of second-round questionnaire for the Resource Depletion policy field

\section{POLICY FIELD DELIMITATION}

Environmental pressure can, in principle, be exerted on natural resources in two ways: resources may be subject to depletion (diminishing the quantity of the resource) and to degradation (deteriorating the quality of the resource). Degradation of the quality of the resource in most cases reduces the availability for human use. The geographical scale is important for natural resources: they may be used in Europe, but the stocks may be depleted elsewhere. In these cases the depletion should be depicted in terms of consumption in the Member States versus global reserves. Where the resources are strictly European, the depletion within the Member States can be depicted.

As to the exact definition of natural resources, there is none. Natural resources are perceived to be many things, depending on the eye of the beholder. The Pressure Indicators Project (PIP) has brought more clarity to 
the question of what natural resources are and, more particularly, what they are meant to be within the PIP.

The PIP is seeking to develop pressure indicators for ten policy fields, more or less derived from the issues within the Fifth Environmental Action Programme (5EAP). The ten policy fields more or less artificially split up various phenomena into several categories. This division is responsible for the placement of biodiversity, water resources, marine resources and waste (all of which may be perceived to be natural resources) into separate policy fields. Also natural resources may be depleted, and degraded by several types of pollution, covered by the remaining policy fields, although these policy fields are mostly defined from the perspective of human toxicity or ecotoxicity and not from the perspective of natural resources degradation. An indication of the relationship between natural resources and other policy issues and economic sectors within the 5EAP is given in Figure 19.2.

The figure shows that there are various relations between the policy fields. It also shows that certain elements are only covered by the policy field of Resource Depletion. The elements on the left: biodiversity, marine resources and water resources (and even waste) may be perceived to be subsets of natural resources. The pollution-oriented policy issues below (water pollu-

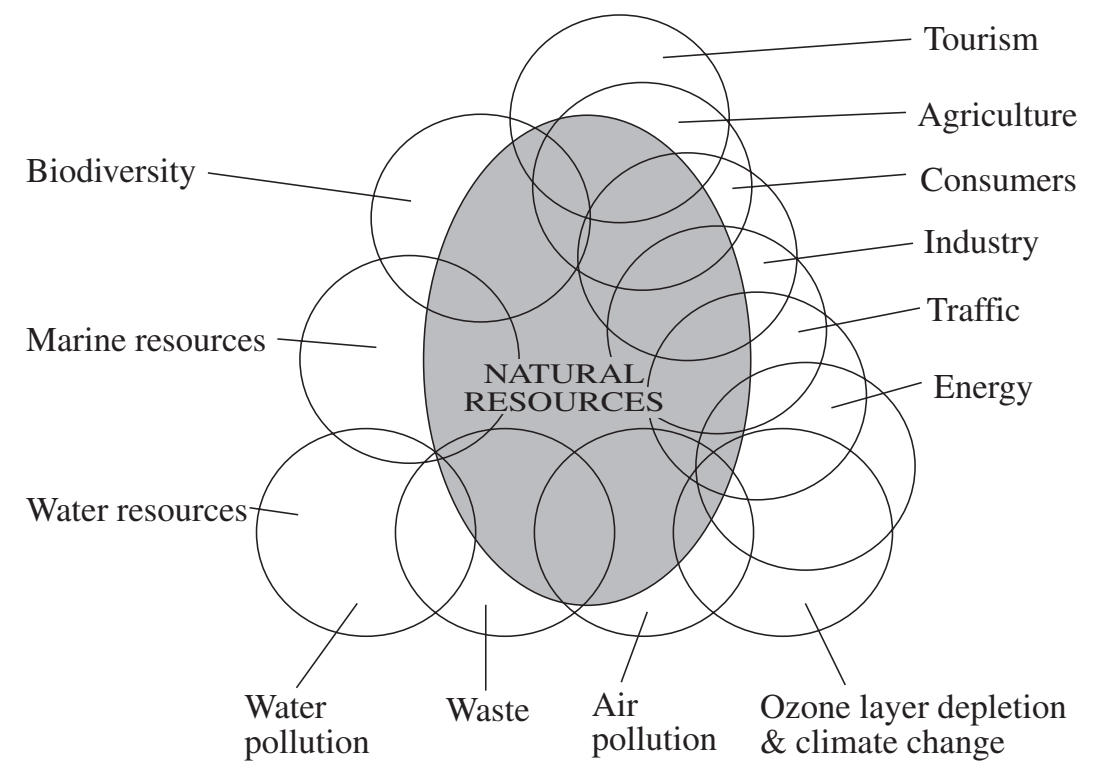

Figure 19.2 Relationship between Natural Resources and other policy issues and economic sectors within the 5EAP 
tion, waste, air pollution, ozone layer depletion and climate change) all have to do with resource degradation. The economic sectors either deplete resources (materials and energy input) or degrade resources (pollution and interventions).

\section{APPROACHES USED IN THE CONTRIBUTIONS}

The contribution were prepared following Eurostat guidelines and a general description of the project. The contributors were asked to describe the following aspects of resource depletion:

1. Resource depletion as a (European) problem

2. The need for national or EU political intervention

3. Short-term and long-term priority actions/measures

4. Expected benefits of a pressure index for natural resources.

Additionally INFOPLAN requested comments on which resources are valuable for European policy development, and whether only resources within Europe should be taken into account, or all resources relevant to Europe.

\section{Similarities and Differences between the Contributions}

The chapters each cover different aspects of resource depletion. Lone covers all resources and comes up with a categorization, classification and selection of resources. Pearce considers the methodological aspects of indicator development and proposes that pressure indicators can feed into measures of sustainability. Weber focuses more on the character of the problems caused by resource depletion and comes up with a selection based on the relative significance of these problems on a European scale.

\section{Resource Depletion as a (European) Problem}

Lone suggests that, in essence, three categories of natural resources may be distinguished:

1. Renewable resources, which may either be inflowing or cyclic

2. Conditionally renewable resources (environmental media or biota)

3. Non-renewable resources, either recyclable or transient.

Although this categorization has its shortcomings, it serves very well to distinguish renewability and depletability. Lone argues that in the context 
of the PIP only conditionally renewable resources are of importance. The condition of renewability is that a certain level of depletion is not superseded. By definition this level would be a sustainability level. Human actions may also degrade renewable resources through disruption of cycles or through pollution. The latter is the subject of other policy fields, as explained above.

Pearce argues that potentials for renewal are an important issue from an economic point of view, using national 'genuine savings' as an example. He states that depletion on the whole is not an issue in the EU as there is no scarcity, but argues that degradation of resources through pollution is an issue.

Weber pleads for the maintenance of, or improvement in, the availability of resources for present and future use, and for the conservation of the potential for renewal of resources. It should be noted, however, that the conditions for renewal are not fixed. They depend on the actual state of depletion or degradation and on the demands for the services to be rendered (and the choice therein). Weber agrees with Lone on the choice of resources, but specifically adds land and ecosystems, by which he means intensified land use by several economic sectors such as agriculture and infrastructure.

\section{The Need for National or EU Political Intervention}

Lone emphasizes the need for management of soils, inland water, wood and fish resources. All of these resources are already the subject of national and international policies, but for these resources he gives arguments for specific European concern.

Pearce argues that the EU should aim towards the creation of a consistent system of sustainable development indicators that goes beyond the pressurestate-response system and that includes the savings and assets of the Member States. His chapter is particularly useful in showing the feasibility of political measures to be taken in the field of resource depletion. People seem to be more than willing to pay for the improvement of the quality of environmental resources. The chapter also demonstrates the necessity for the EU to take political responsibility for natural resources even beyond the EU territory, even though Pearce mostly uses examples within the policy fields of Biodiversity and Water Resources.

Weber argues that a link between environmental and other policies such as economic and social policies is needed. He elaborates this using land and ecosystems as main examples. 


\section{Short-term and Long-term Priority Actions/Measures}

Table 19.1 Recommended actions for the Resource Depletion policy field

\begin{tabular}{lll}
\hline Lone & Weber & Pearce \\
\hline $\begin{array}{l}\text { Reduced grazing and } \\
\text { cultivation intensity } \\
\text { (soil) }\end{array}$ & $\begin{array}{l}\text { Improved energy/ } \\
\text { materials efficiency }\end{array}$ & $\begin{array}{l}\text { Economic accounting } \\
\text { procedures }\end{array}$ \\
$\begin{array}{l}\text { Reduced ground- and } \\
\text { surface-water } \\
\text { withdrawals (water) }\end{array}$ & $\begin{array}{l}\text { Improved land use } \\
\text { planning }\end{array}$ & $\begin{array}{l}\text { Reduced pollution for } \\
\text { agents prioritized by } \\
\text { epidemiology and } \\
\text { economy }\end{array}$ \\
$\begin{array}{l}\text { Reduced deposition of } \\
\text { airborne pollutants, } \\
\text { forest fires, grazing } \\
\text { intensity and removals } \\
\text { (wood) }\end{array}$ & $\begin{array}{l}\text { Enhanced environmental } \\
\text { responsibilities for the } \\
\text { agriculture sector and } \\
\text { transport infrastructure }\end{array}$ & $\begin{array}{l}\text { Continued reform of the } \\
\text { Common Agricultural }\end{array}$ \\
$\begin{array}{l}\text { Policy } \\
\text { Reduced catches of } \\
\text { stocks and species }\end{array}$ & $\begin{array}{l}\text { Support to developing } \\
\text { countries to reduce }\end{array}$ & $\begin{array}{l}\text { Programme on soil } \\
\text { conservation and } \\
\text { decontamination }\end{array}$ \\
\hline
\end{tabular}

\section{Expected Benefits of a Pressure Index for Natural Resources}

Lone sees the benefits in an increase in consciousness and the operationalization of sustainability levels.

Pearce advocates sound and transparent indicators, such as his 'genuine savings', as they best influence both policy-makers and the general public. The benefits lie in public awareness and political embarrassment (for not being 'high up the ladder'). The weighting procedure within the Pressure Indicators Project may also contribute to priority setting, but he would like to see a weighting by more than one societal group (the SAG).

Weber talks of anticipation of problems, understanding of responsibilities and adjustment of behaviour, and would like to see an integral array of pressure-state-response indicators. 


\section{The Framework}

The chapters have contributed to the construction of a framework for Resource Depletion indicators. The SAG suggestions resulted in the construction of a framework with a third category besides depletion and degradation introduced - namely self-sufficiency: the degree to which countries provide for their own demand for natural resources. If this indicator is negative, the country leaves an ecological footprint elsewhere. The SAG suggestions for indicators for Resource Depletion have been clustered into this framework, which is presented in Table 19.2.

The framework produced a list of indicators which was not directly suitable for the second questionnaire to the SAG, as these indicators used percentages and exceedance of sustainable levels as metrics. As explained in the questionnaire, sustainable levels are not yet available and some of these indicators would also not allow the depiction of pressures in relation to economic sectors. Therefore other indicators had to be defined in terms of physical units of measurement and linkages to economic sectors. This produced the list of 27 indicators included in the second-round questionnaire for core ranking and for ranking according to the three quality criteria.

\section{CONCLUSIONS}

The full list of core ranked pressure indicators for the Resource Depletion Policy Field is given in Annex I(B).

- The framework is a helpful instrument in making the policy field of Resource Depletion operational in terms of pressure indicator development.

- The indicators which are directly derived from the framework cover all aspects of the policy field of Resource Depletion.

- The SAG suggestions are not evenly distributed throughout the indicators. This could either be due to a non-random distribution of the expertise within the SAGs, or due to the possibility that the various subjects are not evenly well known among the SAGs. In any case it should not automatically be interpreted as giving insight into the relative importance of the subjects.

- The framework and the derived indicators constitute the infrastructure needed to define sustainability levels for Resource Depletion.

- The ranked indicators enable a prioritization of policy goals. 
Table 19.2 SAG suggestions for Resource Depletion indicators

\begin{tabular}{|c|c|c|c|c|}
\hline $\begin{array}{l}\text { Non- } \\
\text { renewable } \\
\text { resources }\end{array}$ & \multicolumn{2}{|l|}{ Depletion } & \multicolumn{2}{|c|}{ Self-sufficiency ${ }^{a}$} \\
\hline Metals & \multicolumn{2}{|c|}{$\begin{array}{l}\text { Consumption vs global proven } \\
\text { reserves }\end{array}$} & \multicolumn{2}{|c|}{ Production vs consumption } \\
\hline Minerals & \multirow{2}{*}{\multicolumn{2}{|c|}{$\begin{array}{l}\text { Production vs reserves } \\
\text { Consumption vs global proven } \\
\text { reserves }\end{array}$}} & \multirow{2}{*}{\multicolumn{2}{|c|}{$\begin{array}{l}\text { Production vs consumption } \\
\text { Production vs consumption }\end{array}$}} \\
\hline Fossil fuels & & & & \\
\hline $\begin{array}{l}\text { Renewable } \\
\text { resource }\end{array}$ & \multicolumn{2}{|l|}{ Depletion } & \multicolumn{2}{|c|}{ Self-sufficiency } \\
\hline $\begin{array}{l}\text { Non-fossil } \\
\text { fuels }\end{array}$ & \multicolumn{2}{|c|}{$\begin{array}{l}\text { Energy production from wind, water, } \\
\text { solar and nuclear energy sources }\end{array}$} & \multicolumn{2}{|c|}{$\begin{array}{l}\text { Production vs total energy } \\
\text { consumption }\end{array}$} \\
\hline $\begin{array}{l}\text { Conditionally } \\
\text { renewable } \\
\text { resources }\end{array}$ & Degradation & Depletion & & Self-sufficiency \\
\hline $\begin{array}{l}\text { Fresh surface- } \\
\text { water }\end{array}$ & $\begin{array}{l}\text { Acidification above } \\
\text { sustainable level } \\
\text { Salinization above } \\
\text { sustainable level } \\
\text { Eutrophication } \\
\text { (index) above } \\
\text { sustainable level } \\
\text { Human toxicity index } \\
\text { above sustainable } \\
\text { level }\end{array}$ & \multicolumn{2}{|c|}{$\begin{array}{l}\text { Abstraction plus } \\
\text { discharge vs inflow }\end{array}$} & $\begin{array}{l}\text { Production vs } \\
\text { consumption }\end{array}$ \\
\hline $\begin{array}{l}\text { Fresh } \\
\text { groundwater }\end{array}$ & $\begin{array}{l}\text { Acidification above } \\
\text { sustainable level } \\
\text { Salinization above } \\
\text { sustainable level } \\
\text { Eutrophication } \\
\text { (index) above } \\
\text { sustainable level } \\
\text { Human toxicity index } \\
\text { above sustainable level }\end{array}$ & \multicolumn{2}{|c|}{ Abstraction vs inflow } & $\begin{array}{l}\text { Production vs } \\
\text { consumption }\end{array}$ \\
\hline Air & $\begin{array}{l}\text { Human toxicity index } \\
\text { above sustainable level }\end{array}$ & \multicolumn{2}{|l|}{$\mathrm{X}$} & $\mathrm{X}$ \\
\hline Soil & $\begin{array}{l}\text { Fertility (nutrient } \\
\text { balance) } \\
\text { Human toxicity index } \\
\text { above sustainable } \\
\text { level }\end{array}$ & \multicolumn{2}{|c|}{ Soil loss (run-off) } & $\mathrm{X}$ \\
\hline
\end{tabular}


Table 19.2 continued

\begin{tabular}{|c|c|c|c|}
\hline $\begin{array}{l}\text { Conditionally } \\
\text { renewable } \\
\text { resources }\end{array}$ & Degradation & Depletion & Self-sufficiency \\
\hline Territory & $\mathrm{X}$ & $\begin{array}{l}\text { Permanent occupation } \\
\text { by urbanization, } \\
\text { infrastructure, waste- } \\
\text { tipping and quarrying }\end{array}$ & $\mathrm{X}$ \\
\hline Fish & $\begin{array}{l}\text { Percentage of catch } \\
\text { unfit for human or } \\
\text { animal consumption }\end{array}$ & $\begin{array}{l}\text { Fish catch above } \\
\text { sustainable level }\end{array}$ & $\begin{array}{l}\text { Fish production } \\
\text { vs consumption }\end{array}$ \\
\hline Wood & $\begin{array}{l}\text { Vitality index (tree- } \\
\text { health) }\end{array}$ & $\begin{array}{l}\text { Timber balance (new } \\
\text { growth vs harvest) }\end{array}$ & $\begin{array}{l}\text { Wood production } \\
\text { vs consumption }\end{array}$ \\
\hline Biodiversity & \multicolumn{2}{|c|}{$\begin{array}{l}\text { Number of hectares of natural reserves (possibly } \\
\text { divided in classes of quality or ecotopes) }\end{array}$} & $\mathrm{X}$ \\
\hline
\end{tabular}

Note: a It should be noted that self-sufficiency is not necessarily a reliable measure of sustainability when taken alone. A country's production may provide for total national consumption but this does not take into account the exploitation of resources for export.

\section{NOTES}

1. Director of $E^{*} \mathrm{M}^{*} \mathrm{~A} * \mathrm{I}^{*} \mathrm{~L}$, Leiden (NL), see list of Specialized institutes in Annex II.

2. See terminology in Annex IV. 